\title{
Riding the Rails to (Un)Freedom: Colson Whitehead's The Underground Railroad ${ }^{1}$
}

\begin{abstract}
This novel about US black slavery departs from realism, moving around in time and space as a means of dealing with different racial terrors in different historical periods. One of the author's intentions is to make us think about slavery not just in the past but with reverberations for the present. Published in 2016, the novel resonates with a contemporary America characterized by acrimonious racial division. After escaping from a Georgia plantation through a literalized Underground Railroad, the adolescent female protagonist soon learns that freedom remains elusive in states further north, even those where slavery has been abolished. The novel fuses the odyssey of Cora with the history and mythology of America, and asserts the inseparability of slavery from American capitalism and the building of empire. Cora explores both the Declaration of Independence and the Bible, two foundational texts of the nation, in a novel that addresses some of the foundational sins of America. Hers is the all-American story of escape to freedom, but her journey takes her through ever darker varieties of depredation and oppression. She becomes an American dreamer in the sense that she never accepts her place in a system that she persists in defying, and through this process becomes a fictional representation of black people who, with their relentless pursuit of freedom, contributed so greatly to the building of American democracy.
\end{abstract}

Keywords: Colson Whitehead; Underground Railroad; black slavery; runaway slaves

In his Gateway to Freedom: The Hidden History of America's Fugitive Slaves (2015), Eric Foner quotes the abolitionist James Miller McKim, who wrote that fugitive slaves represented "some of the finest specimens of native talent the country provides" and that their actions gave "ample proof" of everything abolitionists maintained about "the capacity of the colored man" (27). In a dispatch written in 1855 as the Philadelphia correspondent of the National Anti-Slavery Standard, McKim made this prediction:

These wonderful events ... now being enacted before the American people, will, one day, be justly appreciated. Now, deemed unworthy of the notice of any, save fanatical abolitionists, these acts of sublime heroism, of lofty self-sacrifice, of patient martyrdom, these beautiful Providences, these hair-breath escapes and terrible dangers, will yet become the themes of the popular literature of this nation, and will excite the admiration, the reverence and the indignation of the generations yet to come. (Qtd. in Foner 27)

With his 2016 novel The Underground Railroad, which won the Pulitzer Prize and the National Book Award, Colson Whitehead has fulfilled McKim's prediction by writing a very popular novel about one of those "finest specimens of native talent," a fictional female slave who escapes from a Georgia plantation in the 1850s. The journey

1 The research for this article was funded by the project USRACEBODY, PGC2018-095687-B-I00, AEI/ERDF, EU. 
of African Americans through American history constitutes the essence of this novel, an African American epic of resistance which becomes the story of America itself. This essay will set Whitehead's novel in the context of the current national conversation about slavery and its consequences, and will relate it to recent historical research that has shed new light on the phenomenon of the so-called Underground Railroad, and also to new studies on the connections between slavery and capitalism. References to other African American writers such as Harriet Jacobs, Frederick Douglass, Nikki Giovanni, Alice Walker, and Toni Morrison will be made along the way, to situate Whitehead's novel in the context of African American literary history.

The railroad has always been a crucially important symbol in African American literature and culture, signifying, among other things, spiritual hope and a vehicle of freedom. In Leon Forrest's novel There Is a Tree More Ancient Than Eden (1973, revised and expanded in 1988), the train is, according to Darcy Zabel, "a symbol of deliverance, but one which carries one away from what is known, including one's own former identity" (52). This Bildungsroman, dominated by the symbol of a train with a mystery man at the controls, is about the quest for identity of the motherless boy Nathaniel Turner Witherspoon. He feels pressured to choose between the demands of his father, who works as a third cook in a luxury train and wants his son to pursue material success, and his Aunt Harriet, a character based on Harriet Tubman, who insists that he should be a spiritual being and transcend the world of man and work for a higher cause, that is to say, remain on track for a special mission (Zabel 53). Zabel provides an insightful assessment of the importance of the train as reality and symbol in African American history and literature:

For African American writers of the twentieth century, however, the train symbolizes more than just a hope for progress or self-improvement. The history of the Underground Railroad, the commitment of Harriet Tubman, the strength of John Henry, the experiences of riding the train North as a passenger, a porter, a stowaway, the sense of again being driven underground in the modern world, all these facets of African American history add to the power of the train as a literary symbol. (31)

The phrase Underground Railroad as a metaphor for the secret network of abolitionists who organized routes and safe houses to guide runaway slaves to freedom in the North appeared in the 1830s, coinciding with the arrival of the railroad as a new system of transportation which, according to Sarah Gordon, provided "a unifying and even orderly influence which aided the country's rapid growth" (8). ${ }^{2}$ The networks that secretly whisked black slaves off to freedom had existed ever since Africans had been forcibly brought to the American colonies in the early 1600s, but, as Kate Larson contends, "By the end of the eighteenth century, however, a more organized system

2 The growth of the underground organization was almost exactly contemporaneous with the expansion of the railroad system itself, which began in the 1830s and transformed the physical and sociological landscape of America as intensely as the abolitionist movement was changing the country's moral environment. In fact, the rapid development of railways increased the speed of underground travelers across the Free States of the North, as the underground used trains when and where they were available (Bordewich 236). 
had started to take shape, one that provided some measure of support to runaways finding their way to freedom" (87).

Historians have lately taken a renewed interest in this little-known subject, in an effort to rescue the Underground Railroad from the fogs of myth and legend and to make it part of the present national conversation about the central role of slavery in American history, one of the results being the rightful place regained by African Americans at the center of the story of the Underground Railroad itself. In his groundbreaking study The Liberty Line: The Legend of the Underground Railroad (1961), Larry Gara questioned the approach of early histories here that merely glorified the work of northern abolitionists, especially Quakers, and he emphasized rather the initiative to escape, coming as it did mainly from slaves. Gara questioned many assumptions about the nature and function of the Underground Railroad, and also about its principal accomplishments. He successfully dismantled the legend of the Underground Railroad as a nationwide underground network of conductors, agents, and depots, the legend that "tells of intrepid abolitionists sending multitudes of passengers over a well-organized transportation system to the Promised Land of freedom" (Gara 2); rather, it was a series of ad hoc and sporadic unconnected escapes. In his revisionist version, "The relatively few slaves who did escape were primarily dependent on their own resources" and "The abolitionists play a less important part and the escaping slaves a more important one" (Gara 18).

In Bound for Canaan (2005), Fergus Bordewich argues that the Underground Railroad "was the country's first racially integrated civil rights movement, in which whites and blacks worked together for six decades before the Civil War, taking great risks together, saving thousands of lives together, and ultimately succeeding together in one of the most ambitious political undertakings in American history" (4). Most of the recent historical research emphasizes the courage and initiative of the many black people, both enslaved and free, whose actions gave the lie to those pro-slavery ideologues who maintained the inability of blacks to take their destiny into their own hands and to exercise individual initiative. In Making Freedom: The Underground Railroad and the Politics of Slavery (2013), R. J. M. Blackett also notes the role of slaves in seeking freedom and makes them key figures in the construction of what we know as the Underground Railroad, and ultimately in helping to bring about the collapse of slavery. Blackett reiterates some of the points made by Larry Gara: "my focus is on the slaves as well as those who aided them where it mattered most: in the South" (2), the South from which some slaves escaped to avoid being punished or sold, or because masters had failed to fulfill promises, or to join family members who had escaped earlier. Blackett concludes that "They were well aware of what they were doing and the consequences of their actions" and that "whatever the specific reasons for leaving, collectively their actions were informed by what E. P. Thomson has called a 'general notion' of rights and a passionate desire for freedom" (95), ${ }^{3}$ thus disproving notions of slaves as content and spineless.

In The Underground Railroad from Slavery to Freedom (1898), the first major historical study of the phenomenon, Wilbur Siebert traced and gave the names of 3,211 individuals involved in the underground, almost all of them white men. Bordewich

3 E. P. Thompson. Customs in Common (New York: The New Press, 1991, p. 212). 
argues that at least three or four times the number of people estimated by Siebert must actually have worked on the Underground Railroad, and that Siebert "failed to take into account the large numbers of African Americans - possibly the majority who risked their lives to help fugitives, or the fact that women who provided refugees with food, clothing, and advice were as much a part of the underground as were their husbands and brothers" (437).

Another myth that recent scholarship has debunked is the conception of the Underground Railroad as a fixed, centralized, and unaltered system. As Bordewich explains, "In actuality, routes were always in flux. Even as new routes were opened, old ones became too dangerous, or no longer practical, and were abandoned. Participants died, moved, dropped out, or were driven out of the business by threats" (230). Local networks rose and disappeared over time and the image of a secret organization of abolitionists using covert methods and secret signals to carry slaves to freedom through more or less clearly defined routes is rather simplified. Rather than a single entity, Eric Foner conceives the Underground Railroad as "an umbrella term for local groups that employed numerous methods to assist fugitives, some public and entirely legal, some flagrant violations of the law" (15).

In an interview with Publishers' Weekly, Whitehead referred to his discomfort when people asked him what he was trying to say in this novel: "I'm not a teacher, I'm not a historian; I'm trying to create a world for my characters." He also said that he hoped people would "maybe think about American history in a different way," referring to the contemporary relevance of the problem of slavery which he hoped people would see anew (Patrick 28). We inevitably reassess the past in light of the present, and there is a sense in which all history is contemporary history, and that the past somehow changes with the present. As Ira Berlin argues at the opening of his study of Emancipation, "History is not about the past; it is about arguments we have about the past. And because it is about arguments that we have, it is about us" (1). According to the black writer James Baldwin, "History is not the past. It is the present. We carry our history with us. We are our history" (107). The appearance of Whitehead's novel about slavery not only coincided with the recent historical reappraisal of the nature and historical significance of the Underground Railroad; it obviously resonates with the acrimonious ongoing debate about racism, the most critical contemporary social problem in America. In an interview with Time magazine, he said: "But if the way I handle different periods of American history and black history does illuminate the way we live now in a way that's useful, I'm glad"' (R. Jones 48). There is no doubt that Whitehead intended this novel to become a part of the important national conversation about the nature of slavery and its consequences, about Black Lives Matter, ${ }^{4}$ about the story of black Americans being a story of the path "from the Plantation to the Prison,"

4 Black Lives Matter is a movement against police brutality and against all forms of discrimination in all social areas, created in 2013 by three black activists: Patrisse Cullors, Alicia Garza, and Opal Tometi.

5 From the Plantation to the Prison (ed. Tara T. Green, Macon: Mercer UP, 2008) is a collection of essays about the history of the confinement of African Americans viewed as a physical and sometimes spiritual state. It explores texts of African American confinement literature set in a place of confinement, including plantations, prisons, and segregated environments. 
at a time when there are more black people held in criminal supervision than all the slaves in the 1850s. In her study The New Jim Crow: Mass Incarceration in the Age of Colorblindness (2010), Michelle Alexander shows how mass incarceration is actually re-enslaving African Americans in a nation in which many blindly believe that racism is dead. ${ }^{6}$

In his essay "Slavery and Historical Memory in Late-Twentieth-Century Fiction," Ashraf Rushdy discusses new modes of black fiction like Ishmael Reed's flippant and humorous Flight to Canada (1976) and Octavia Butler's use of time travel in Kindred (1979), and asks if "contemporary authors [could] make positive use of their distance from antebellum slavery to take liberties and assume freedoms in their playful innovation and experimentation with form, genre, and tone" (237). Like Octavia Butler in Kindred, Whitehead also uses time travel to show us how the past affects and has implications for the present. The main conceit of the novel is as simple as it is daringly original. The Underground Railroad here is more than the secret network of abolitionists who organize routes and safe houses to guide slaves from southern plantations to freedom in the North: in the safe houses you open a trap door or find the entrance to a secret cave and you reach an actual railroad, with actual engines and boxcars, and conductors, sometimes even benches on the platform. The trains show up at unpredictable times and go to uncertain destinations. The idea came to the author fifteen years before he began the novel: "In school, hearing about the Underground Railroad, your first thought, at least for a minute, was that it was a literal subway - which made me wonder, what if the Underground Railroad was an actual railroad, literally underneath the earth?" (Patrick 27).

Whitehead sends his protagonist, the 15-or-16-year-old Cora, on a journey through different states: South Carolina, North Carolina, Tennessee, and Indiana, following the structural model of Gulliver's Travels. As he says, "So each [state] is a sort of island, in a Gulliver's Travels kind of way" (Patrick 28). The realism of the subject is balanced with fantastic touches modeled on García Marquez's A Hundred Years of Solitude. ${ }^{7}$ Whitehead is fond of taking liberties with his settings and his time frames, and the point is to have the Railroad carry his protagonist through different Americas, through different phases of the black experience of perpetual unfreedom and inhospitality. Thus it is that Cora travels through an America in which "All men are created equal, unless we [whites] decide you are not a man" (182).

There are two crucial questions in contemporary historical renditions of slavery: the question of agency, and the connections between slavery and American capitalism. We have already referred to the recent engagement with the history of the Underground Railroad on the part of revisionist historians who cleared away the mist of myth and legend and stressed the active role of African Americans. Nowadays history gives a different version of slavery, forcefully rejects the myth of the happy-go lucky slave, and takes far more seriously the incidence of slave resistance, of brave individuals who risked their lives by fleeing and fighting slavery. The new social

6 Schuessler explicitly mentions Alexander's book as one of Whitehead's influences for the novel.

7 Whitehead said: "I went back and reread One Hundred Years of Solitude, and it made me think about what it would be like if I didn't turn the dial up to 10, but kept the fantasy much more matter-of-fact” (Schuessler). 
historians insist that abolition was not an issue of white saviors rescuing passive black victims, and they devote due attention to an active black resistance that for too long remained unacknowledged. Ira Berlin's The Long Emancipation (2015) and Manisha Sinha's The Slave's Cause: A History of Abolition (2016) recover the largely ignored role of African Americans in the long fight for emancipation, whose most important characteristic was the will to survive and the enduring resistance of enslaved blacks themselves. According to Sinha, "Critiquing and perfecting American democracy was the black man's burden" (299). Berlin shows how African Americans, free and enslaved, stood at the vanguard of abolitionism, demanding not only freedom but also full citizenship, often seeking inspiration in the Bible and the Declaration of Independence.

In a most resonant episode in the novel, the protagonist's runaway companion asks a station agent who built the Railroad's tunnels and stations, and the answer is: "Who builds anything in this country?" (67), which reminds us of how much of America was built by black workers. In The Half Has Never Been Told: Slavery and the History of American Capitalism, Edward Baptist, one of the historians Whitehead explicitly acknowledges as an influence, notes that "Enslaved African Americans built the modern United States, and indeed the entire modern world, in ways both obvious and hidden" (xxv). Baptist maintains that slavery was not the pre-modern pre-capitalist institution that Eugene Genovese described in the early 1960s, something isolated in the past and with no connection to America's later economic success; ${ }^{8}$ on the contrary, racial slavery was central to American economic development and national power, and the slave South was distinctively modern in terms of capitalist management. The untold half of the story that Baptist reveals is that enslaved Africans survived forced migration to the cotton-based South and then shaped the modern world through their labor, survival, and resistance. Cotton was the single most important commodity in the global economy of the late eighteenth and the first half of the nineteenth centuries, the essential raw material of the factory revolution that launched the global economy on its modern course. Whitehead's novel takes place in the 1850s, when cotton was booming, and it opens with the story of Cora's grandmother, Ajarry, kidnapped in Africa and brought to America: "Since the night she was kidnapped she had been appraised and reappraised, each day waking upon the pan of a new scale. Know your value and you know your place in the order. To escape the boundary of the plantation was to escape the fundamental principles of your existence: impossible" (8).

This issue of extreme dehumanization that turns people into assets is obsessively emphasized in the early stages of the novel, when Cora is on the plantation. The master is a "savvy businessman" who "when black blood was money ... knew to open the vein" (23). As "the world's insatiable demand for cotton goods" grows, the plantation owner demands a reorganization of the fields and more work from each hand "to accommodate a more efficient number of rows" and an increase in every picker's daily

8 In The Political Economy of Slavery: Studies in the Economy and Society of the Slave South, Eugene Genovese argues that "The planters were not mere capitalists; they were precapitalist, quasi-aristocratic landowners who had to adjust their economy and ways of thinking to a capitalist world market. Their society, in its spirit and fundamental direction, represented the antithesis of capitalism, however many compromises it had to make" (23). 
quota (47). Historians like Baptist have recently documented how methods of torture became more brutal and sophisticated, with the aim of turning enslaved bodies into commodities with which the financial history of the western world was transformed (Baptist xxviii). John Brown, a fugitive slave, said in 1854: "When the price [of cotton] rises in the English market, the poor slaves immediately feel the effects, for they are harder driven, and the whip is kept more constantly going" (qtd. in Beckert 110). The expansion of cotton manufacturing in Great Britain depended on brutal coercion and violence in the southern plantations. Cotton flowed from the United States to Europe and the capital that flowed in the opposite direction was often secured by mortgages on slaves. Cora actually decides to escape soon after her master, financed by the Bank of England, decides to plant cotton, and perfects the means of torture to increase production, which coincides with his beginning to touch and squeeze her breasts (47), in a system in which, as we read in the Ajarry section, "A slave girl squeezing out pups was like a mint, money that bred money" (6-7).

The agent at the first Railroad station encourages Cora and her companion to take the train despite its uncertain destination: "Every state is different. Each one a state of possibility, with its own customs and way of doing things. Moving through them, you'll see the breadth of the country before you reach the final stop" (68-69). The novel has the episodic structure of Adventures of Huckleberry Finn and builds on the inherently American motif of the journey, in this case to express the painful journey of African Americans through American history. The idea of the train journey is, for Cora and her runaway companion, Caesar, to "find the true face of America" (69). Later in the novel, Cora remembers the words of the first station agent and concludes that "It was a joke, then, from the start. There was only darkness outside the windows on her journeys, and only ever would be darkness" (262-63). As James Baldwin said, "The story of the Negro in America is the story of America. It is not a pretty story" (95). Cora is tied to American history and mythology as is Fitzgerald's Jay Gatsby, but Gatsby embodies the history of white America. The Great Gatsby is about the inevitable failure and corruption of the Dream of white settlers who eventually turned a dreamland into a wasteland. But Fitzgerald's novel ignores the fact that "the American Dream is at the expense of the American Negro," as James Baldwin maintained in his 1965 Cambridge University debate with William F. Buckley, and it does not refer to the human tools that made the country, the slaves that in Whitehead's novel the renowned patroller Ridgeway returns to their owners, using "his facility for ensuring that property remained property" (80). He relentlessly plays his part as a tool in a system that dehumanizes both blacks and whites, making them tools and parts in the machine of empire.

Ridgeway is the Ahab-like slave catcher that relentlessly pursues Cora wherever she goes. Described in his first appearance as "burly and resolute" (74), he has the intense concentration of Melville's monomaniacal captain, and is equally obsessed by the relentless chase: "In the chase his blood sang and glowed" (76). A product of the fear and anger that the Underground Railroad provoked in the South, which led to draconian legislation that eroded even the rights of white Americans in the North, he represents the Fugitive Slave Act of 1850 which, according to Ibram Kendi, "handed enslavers octopus powers, allowing their tentacles to extend to the North" and 
"criminalized abettors of fugitives, provided northerners incentives to capture them, and denied captured Blacks a jury trial, opening the door to mass kidnappings" (18990). Ridgeway's appearance in all the different places and historical periods that Cora traverses represents the recurrence of black exploitation, which adopts different guises, depending on the place and the historical period. His actions are dictated by what he calls "the American imperative," which consists of "lift[ing] up the lesser races. If not lift up, subjugate. And if not subjugate, exterminate" (222). In a different way from Cora, Ridgeway is also a victim of the destructive wandering imposed by the logic of empire on both pursuer and pursued.

Whitehead's novel is, among other things, about the consolidation of a white nation in which, as Ridgeway observes, destitute European immigrants are arriving in New York City, "Hapless as niggers, by any measure. But they'd be called to their proper places as he had been" (79). Aware that his own situation down in the South is nothing but "a ripple of this first arrival," he notices that "The possibilities lay before these pilgrims like a banquet, and they'd been so hungry their whole lives" (79). The color of their skin would favor material prosperity and "they' $d$ leave their mark on this new land, ... making it theirs through unstoppable racial logic" (79-80), a "racial logic" that dictates that the advancement of these "pilgrims" in the new nation will depend on the enslavement of blacks and the dispossession of Natives. In North Carolina, the poor Irish servant girl who, for a reward, sneaks on Cora and the white couple hiding her, says, "A girl's got to look after her interests if she's going to get ahead in this county" (187), the American Dream thus becoming inseparable from treachery and inhumanity. Some of these poor immigrants did indeed channel their initial economic and political frustrations into racist ideas, and this led to more hatred of black people (Kendi 170). As Khalil Muhammad observes, "Whiteness scholars have shown how the attributes of skin color, European ancestry, and the gradual adoption of anti-black racism were crucial to immigrant assimilation into the singular "white race"" (6). Ibran Kendi notes that racist ideas conditioned the minds of people arriving in the US in the early 1900s and observes that "When Irish, Jewish, Italian, Asian, Chicana/o, and Latina/o people in America were called anti-Black racial epithets like 'greasers' or 'guineas' or 'White niggers', ... most [of them] probably consumed the racist ideas, distancing themselves from Black people" (285-86). Manisha Sinha maintains that, in the years immediately before the Civil War, "immigrants' hostility to abolition was the result of a process of Americanization through which they sought to accrue the benefits of 'whiteness' and hypernationalism or demonstrate loyalty to their adopted country" (360).

In one of the most famous passages of his Narrative, Frederick Douglass quotes one of his masters as saying: "Now, if you teach that nigger how to read, there would be no keeping him. It would forever unfit him to be a slave. He would at once become unmanageable, and of no value to his master. As to himself, it could do him no good, but a great deal of harm. It would make him discontented and unhappy" (29). Whitehead's novel digs into the established tradition in African American literature and culture that the journey away from slavery is simultaneous with the journey toward education. In the section about Caesar, Cora's traveling companion in the first leg of the journey, we learn that "if he didn't read, he was a slave" (235). 
Cora takes full advantage of every opportunity that she has to learn to read and figure out the world. During her captivity in North Carolina she explores both the Declaration of Independence and the Bible, two sacred foundational texts. According to Ira Berlin, one of the new historians who contend that the most important factor in bringing about emancipation was the will to survive and the enduring resistance of enslaved blacks themselves, which are precisely the impulses that Cora embodies, "black people in the United States not only raised the question of their post-emancipation standing, but answered it as well, drawing on their commitment to ideals articulated in the Declaration of Independence and in biblical precepts of evangelical Christianity" (10). The free black population grew simultaneously with a nation formally committed to liberty and equality, so "black people adopted it [the Declaration] as their ideal and became its most steadfast defenders" (10). More in line with our time's Afro pessimists such as Ta-Nehisi Coates, who reject the optimistic notion of a post-racial America, Cora sees the foundational sins of America and perceives the Bible's contradictions about slavery, which is "a sin when whites were put to the yoke, but not the African" (182). And after seeing some of the country, Cora is not sure that the Declaration "described anything real at all. America was a ghost in the darkness, like her" (180).

With his cruel cynicism, Ridgeway indirectly instructs Cora. He tells her about Manifest Destiny, which for him is anything but "a new idea," but only "taking what is yours, your property, whatever you deem it to be. And everyone taking their assigned places to allow you to take it. Whether it's red men or Africans, giving up themselves, giving of themselves, so that we can take what is rightfully ours" (221). The phrase was coined by John O'Sullivan, editor of the Democratic Review. He was a fervid expansionist who supported the annexation of Texas and the expansion of the nation and of slavery to the West. To counter the first published copies of Frederick Douglass' Narrative (1845), O'Sullivan wrote in the July 1845 issue about AngloSaxon Americans' "manifest destiny to overspread and to possess the whole continent which Providence has given us" (qtd. in Kendi 186).

The first stop on Cora's journey is in a surreal South Carolina with skyscrapers, where slavery has been abolished and the Civil War seems never to have happened. It is a paternalistic state where whites are engaged in "their mission of colored uplift, especially for those with aptitude" (98). The government is buying blacks, and they are given rooms and schooling, but they are technically "the property of the United States government" (92). Cora is first employed as a house servant for a rich family and is later made a slave to white commemorations of falsified history when hired to perform as a live mannequin acting her part in a depiction of the slave experience in the Museum of Natural Wonders, with white visitors looking at her intensely from the other side of the glass. Thus is she objectified and made into a side-show freak in a culture characterized by its myopic and restrictive understanding of the racial Other. Whitehead is interested in reflecting the many ways in which black history has been stolen and re-written by white narrators, noting the following in an interview: "But I did want to talk about how world fairs would exhibit black people as jungle natives" (R. Jones 48). Cora actively questions the accuracy of the static scenes of black life that make up the diorama and she decides to look back, to stare down the white spectators and give them the "evil eye" (125). The exhibits of white people have no live models, 
and the whites are free, they are masters, as shown in the figures of pioneers: "They were masters of their lives, lighting out fearlessly into their futures" (115), a satirical allusion to the white icon Huck Finn who at the end of Twain's novel announces his intention "to light out for the Territory ahead of the rest."

It turns out that under the paternalistic facade of care and uplifting, South Carolina is busy preparing a sinister future for former slaves. Cora discovers that there is a long-term project of solving the "Negro problem" through eugenics and sterilization. The new hospital is conducting medical experiments, infecting black men with syphilis and sterilizing black women, to prevent blacks from outnumbering whites. And what we are presented with here is an America much closer to the present; it sounds outlandish, but perhaps it is not, especially when we remember the sickening experiments with black men in Tuskegee, Alabama: an infamous clinical study was conducted between 1932 and 1972 by the US Public Health Service to study the natural progression of untreated syphilis in African American men; 399 poor black sharecroppers from Alabama were never told that they had syphilis and were not given the penicillin that could have cured them; another 201 black men served as controls. This experiment, conducted by a government agency, made many people recall Nazi Germany and equate it with genocide (J. Jones 12). In Whitehead's fictional South Carolina black men are given "their blood treatments" (112), an obvious allusion to the guinea pigs in the Tuskegee experiment who were told that they were being treated for "bad blood" (J. Jones 5). Cora is encouraged to undergo "a new surgical technique wherein the tubes inside a woman were severed to prevent the growth of a baby" (113). According to Dorothy Roberts, "During the 1960s and 1970s, thousands of poor black women were coercively sterilized under federally funded programs. Women were threatened with termination of welfare benefits or denial of medical care if they didn't 'consent' to the procedure. Southern blacks claimed that black women were routinely sterilized without their consent and for no valid medical reason-a practice so widespread it was called a "Mississippi appendectomy" (Roberts). Whitehead's anachronism is no doubt intended to make the point that the depredation and suppression of the black body continued long after Abolition.

In the North Carolina depicted in the novel they have abolished slavery because they now employ "white niggers" (poor immigrants) to do the farm work, but they are intent on abolishing all blacks as well, and the place is ruled by brutal white supremacists. Cora enters the unnamed town, staying on a road called "Freedom Trail" (152), on the side of which is a long line of lynched bodies hanging from trees. The only blacks she sees in the place are "at the ends of ropes" (156). Julian Lucas finds echoes here of the 1898 Wilmington Insurrection, when the city's interracial government was deposed by a mob of white supremacists, who shot or lynched dozens of African Americans, an event which was part of the so-called redemption of the South and was followed by more than fifty years of segregation (56).

In North Carolina Cora spends an unspecified period of time hidden in a "cramped nook" (154) above a false ceiling in the attic of the house of the local station agent, where "the only source of light and air was a hole in the wall that faced the street" (154); a "suffocating nook" (157) reminiscent of the attic, also in North Carolina, where Harriet Jacobs, writing as Linda Brent, hid for almost seven years in 
order to escape from slavery. ${ }^{9}$ The self-chosen imprisonment in what Jacobs terms "a dismal hole," "my little cell," or "my dungeon," is, nevertheless, better than slavery: "This continued darkness was oppressive. It seemed horrible to sit or lie in a cramped position day after day, without one gleam of light. Yet I would have chosen this, rather than my lot as a slave" (Jacobs). In a similar vein, Cora muses on the paradoxes of her captivity, in a puzzling world "that makes a living prison into your only haven" (179). And, like Jacobs, Cora converts the tomb into a womb, a source of life and learning. During her captivity in this claustrophobic nook with notorious gothic overtones, she improves her reading skills and sharpens her critical thinking, through interactions with her hosts and through the spectacle she sees in the square outside through the hole in the wall. Every Friday the whites gather in the park for a festival, with music, a "coon show" (157) in which whites with blackened faces perform as stupid blacks, a morality play about the futility of slaves escaping to the North (157), and culminating in a lynching festival. The matter-of-fact description of the party atmosphere may seem fantastic and grotesque, but not if we remember the celebratory atmosphere that characterized the lynching of so many African Americans. North Carolina constitutes a very important stage, in which Cora, as has already been noted, reads and questions the Bible and the Declaration of Independence. As Laura Dubek observes, by watching the townspeople she "gets an education in the politics of white identity construction" (76). Cora sees through the inconsistencies of whites, who are perfectly happy to live in a sort of Nazi police state in which she is like a black Anne Frank, and who "were prisoners like she was, shackled to fear," fear of retaliation on the part of "the rising black tribe" (179), fear of their own neighbors who could concoct false accusations of wrongdoing or report on protectors of runaways.

But it is not just the whites who are perverted and paralyzed by fear. With Cora's capture in North Carolina by the relentless Ridgeway, a new character is introduced into the story, a black ten-year-old boy named Homer who works as the slave-catcher's assistant and accountant and wears a "tailored black suit and a stovepipe hat" (187). He never shows racial affinity for Cora or any of the other captives. Ridgeway had bought Homer in Atlanta and freed him, but Homer stayed with him. He is one of those people who exhibit a false consciousness and prefer a sense of security to the personal autonomy Cora is ready to kill for. A quintessential instance of what Erich Fromm termed fear of freedom, Homer can only sleep well after he chains himself: "Each night, with meticulous care, Homer opened his satchel and removed a set of manacles. He locked himself to the driver's seat, put the key in his pocket, and closed his eyes" (203). Cora is self-critical enough to acknowledge her internal division, with the coexistence of "the slave part of her" and "the human part of her" (34). In sharp contrast with Cora, Homer is dominated by his "slave self" and seems to have internalized the prevailing notions of black inferiority in a form of black self-contempt. In The Problem of Slavery in the Age of Emancipation (2014), David Davis shows how the assumptions of black inferiority and incapacity for freedom that had been used as a fundamental justification for slavery were held not only by whites but also affected some blacks - those that "failed to see their own oppression since

9 Harriet Jacobs' Incidents in the Life of a Slave Girl is actually one of the sources Whitehead acknowledges for his novel. 
they had internalized the whites' definition of their own identity and even felt a sense of duty and indebtedness to their more paternalistic masters" (213). The escaped slave and black abolitionist Henry Harland Garnet described the intentions of enslavers thus: "They endeavor to make you as much like brutes as possible. When they have blinded the eyes of your mind," then slavery has "done its perfect work" (Garnet). Slavery, or any other system of oppression, is more difficult to defeat when there is some kind of consent on the part of the oppressed. As Ira Berlin notes, "Asserting the primacy of black abolitionists likewise does not deny that many black people did little to aid the struggle for universal freedom, whether because of their indifference, their fear, their feelings of powerlessness, or their active opposition to abolition" (34-35).

The last two stages of Cora's journey include one of traveling, as Ridgeway's captive, through a Tennessee where the land has been burned, because of a fire that was started to clear land stolen from the Indians; that is, the soil of a Native South that preceded the South as the political-cultural imagined community that it has been since the first decades of the 19th century. The other stage is a brief stay at a flourishing farming community of black people in Indiana, where runaways are welcome to stay. But Cora soon learns that the "Whites Only" nightmare is spreading upwards from the South (277) and that, in terms of racism, the whole country is the South. The farm is eventually ambushed by whites bent on destroying what they cannot control: a reminder of episodes like the furious whites burning down the successful black business section of Tulsa, Oklahoma, called the "Black Wall Street," in 1921. Thus Cora is once again excluded from the home that she yearns for and which her country does not want her to have. The only shelter she has ever had, and still keeps on her memory, is the small garden she tended in the Georgia plantation.

At the end of Voltaire's story "Candide" the protagonist says, "We must cultivate our garden." He is not speaking about paradise regained; he has seen the world and it is full of misfortune and negativity, but the return to something close to home brings meaning, the meaning that resides in the struggle, even if there is no hope that we will ever be wholly free. The little garden plot that was begun by her grandmother Ajarry and that she inherited from her mother remains a dear and powerful memory for Cora throughout. Even when it is just a memory, "a shadow of something that lived elsewhere, out of sight" (179-80), it is the only thing of her own, the only spot in the plantation where she is a human that momentarily escapes a culture of slavery. The plot that she defends tooth and nail is expressive of the rebellious spirit that Cora inherited from her runaway mother and that impels her to take action rather than be acted upon, of her resistance to abuse and thingification. As Caesar, Cora's runaway companion, perceives, "She knew the preciousness of what little she called her own. Her joys, her plot, that block of sugar maple she perched on like a vulture" (232). Cultivating the garden is not only an avenue for African American selfexpression that Alice Walker explores and celebrates in her essay "In Search of Our Mother's Gardens" (1974), but also a way of resisting the predation of what Orlando Patterson calls "social death," the dehumanization pursued by enslavers. The garden is a site of resistance, a way of showing that the institution of slavery did not work because it did not render all slaves servile: in her garden Cora "owned herself for a few hours every week" (12); it is "An anchor in the vicious waters of the plantation" 
(55), the proof that slavery does not destroy creativity in African Americans. With her gardening, Cora refuses to give in to circumstances and defies the stereotype of the brutish and uncultivated black person who excels only in forced physical labor. As in Alice Walker, the garden is related to family heritage and continuity: passed on from Ajarry through Mabel to her daughter Cora, it is "The most valuable land in all of Georgia" (294). This heavily symbolic garden is also reminiscent of the garden of Miss Ethel, the old, healing African American woman who restores the protagonist's sister to health in Toni Morrison's Home, a garden that "was not Eden; it was so much more that that" (130).

In The Scary Mason-Dixon Line, Trudier Harris argues that the South has always shaped the imagination of African American writers, whether or not they were born in the South, and that their conception of the southern territory "helps to understand creativity operating under the influence of history as well as under the influence of race" (1). Persuaded that "the American South ... becomes a rite of passage for African American writers" and that "Not one of them considers himself or herself truly an African American writer without having confronted the South in some way" (2), Harris describes the South as the mountain that black writers, even if they are nonsoutherners, like Whitehead, have to tunnel through: "Tunneling through the mountain of the South enables them to arrive at the other side with a heightened sense of who they are as writers. Complete identity as an African American writer seems to come only after a confrontation with black history and American history as represented by and in the South" (16). In "North," the last section of Whitehead's novel, there is a passage in which Cora seems to be a representation of Whitehead tunneling his way as a black writer thorough that southern mountain of repression and violence. In her last ride on the Railroad we see Cora, after hitting Ridgeway and escaping from him, going into a tunnel "no one had made, that led nowhere" (303), in a handcar, as if she were simultaneously riding and building the Railroad. It is probably the most powerful passage in the novel, about the urge to go anywhere but back to slavery, a very intense and ambivalent passage: "Was she traveling through the tunnel or digging it?" (303). The passage celebrates the moral triumph of the effort that built a miracle like this Railroad: "The ones who excavated a million tons of rock and dirt, toiled in the belly of the earth for the deliverance of slaves like her" (303). From the beginning, Cora has stood for the many black people who with their relentless pursuit of freedom and their denunciation of a dehumanizing system carried "the black man's burden" of perfecting American democracy. Actually, Caesar had chosen her as his runaway partner because she was not just good luck but "the locomotive itself" (234).

In "One More Boxcar" (1999), Nikki Giovanni's poem about the Underground Railroad, the narrating voice sees him or herself as "one more boxcar" resolutely "inching along" toward freedom (24). The Underground Railroad itself becomes a person, and individual runaways become their own vehicles of escape. Each runaway becomes a boxcar and, moving single-file, together they form an endless train of people on their way to freedom. According to Darcy Zabel, the poem suggests that the real Underground Railroad "was composed of the individuals who never actually boarded a train, received no help, and made the journey alone, inch by inch." Giovanni is suggesting that "History and heroism ... is written not in milestones but in inches" 
and that "The slow, individual creep toward freedom becomes a massive force to be remembered when all the inches are measured up in miles" (71). Both Giovanni in her poem and Whitehead in this passage suggest that instead of waiting for the Underground Railroad that would never really come to their rescue, it was the individual runaways who, with their own bodies, became their own vehicles of salvation. Cora here rightly claims the right to belong in the American mythology of renewal and the existential belief that we can continually remake ourselves and transform our weaknesses into strengths: "On one end there was who you were before you went underground, and on the other end a new person steps out into the light" (304). In other words, the fight can go underground for strategic purposes, but it cannot be destroyed, and to board the train you have to leave behind the known world of an old identity and become a new person at the end of the journey. One of the most important mythological figures in black literature and culture is John Henry, the Herculean builder of railroad tracks, who symbolically builds himself at the same time as he builds America. ${ }^{10}$

Cora finally finds her way out of the tunnel through a cave, and at the very end she is like a pioneer, when she gets on a wagon, driven by an old black man, going West, first to Missouri and from there maybe to California, a twenty-first century version of Martin Luther King Jr.'s long-deferred dream of a promised land, and a probable echo of Shirley Anne Williams' Dessa Rose (1986), a novel in which the final flight of fugitive slaves is not to the North, as in the traditional political geography, but to the West, to the non-slave territory, the frontier, the soil of which Ralph Ellison, according to Harris, said that it "enabled black human beings to picture themselves as Renaissance people, able to do and be whatever they wanted to be" (Harris 96). Williams and Whitehead thus combine the African American Tubman tradition of slaves riding the Underground Railroad to freedom in the North with the white epic of pioneers moving westward.

For Cora it is anywhere rather than going back, and her surviving slavery, an institution based on dehumanization and thingification, is the most effective way of showing that it did not work because it did not break the will of slaves to fight. Whitehead sees the closing pages as optimistic, but also realistic: "I find the last pages very hopeful. But still, wherever we go, we're still in America, which is an imperfect place. That's the reality of things" (Schuessler). Cora is still running away, still without the home her country doesn't want her to have, without a community where she can build and belong unhindered. The novel has taken us through successive phases that begin with promises of potential and soon end in tragedy and dispossession brought about by white supremacy. It is, as one reviewer has said, "As though to remind us that the tragedy of slavery was not what happened but what never happened because of it" (Lucas 57). She continues to be in transit, like a refugee, and that is how black people have always been treated as a population in America. In her essay "Message to My Daughters," Edwidge Danticat contends that black people in America have always been treated as a population in transit, housed and educated in conditions not much better than those of refugees. As a black Haitian immigrant, she complains about "the precarious nature of [black] citizenship here: that we too are prey, and those who have been in this country for generations - walking, living, loving in the same skin

10 Colson Whitehead wrote a novel titled John Henry Days (2001) about this legendary figure. 
we're in - they too can suddenly become refugees" (210-11). For Cora, the world has always been one with "no places to escape to, only places to flee" (257), and her story reaffirms our perception that the Underground Railroad has not reached its destination yet.

\section{Works Cited}

Alexander, Michelle. The New Jim Crow: Mass Incarceration in the Age of Colorblindness. Rev. ed. New York: The New Press, 2012. Print.

Baldwin, James. I Am Not Your Negro. Comp. and ed. Raoul Peck. London: Penguin, 2017. Print.

Baptist, Edward E. The Half Has Never Been Told: Slavery and the Making of American Capitalism. New York: Basic, 2014. Print.

Beckert, Sven. Empire of Cotton: A Global History. New York: Vintage, 2015. Print.

Berlin, Ira. The Long Emancipation: The Demise of Slavery in the United States. Cambridge: Harvard UP, 2015. Print.

Blackett, R. J. M. Making Freedom: The Underground Railroad and the Politics of Slavery. Chapel Hill: U of North Carolina P, 2013. Print.

Bordewich, Fergus M. Bound for Canaan: The Epic Story of the Underground Railroad, America's Fist Civil Rights Movement. New York: Amistad, 2005. Print.

Danticat, Edwidge. "Message to My Daughters." The Fire This Time: A New Generation Speaks about Race. Ed. Jesmyn Ward. New York: Scribner, 2016. 205-15. Print.

Davis, David Brion. The Problem of Slavery in the Age of Emancipation. New York: Vintage, 2015. Print.

Douglass, Frederick. Narrative of the Life of Frederick Douglass, An American Slave. Boston: The Anti-Slavery Office, 1845.

Dubek, Laura. "'Fight for It!': The Twenty-First-Century Underground Railroad." The Journal of American Culture 41. 1 (March 2018): 68-80. Print.

Foner, Eric. Gateway to Freedom: The Hidden History of America's Fugitive Slaves. Oxford: Oxford UP, 2015. Print.

Gara, Larry. The Liberty Line: The Legend of the Underground Railroad. Lexington: U of Kentucky P, 1961. Print.

Garnet, Henry Highland. "An Address to the Slaves of the United States." Delivered at the National Negro Convention of 1843 held in Buffalo, NY.

http://www.blackpast.org/1843-henry-highland-garnet-address-slaves-unitedstates. Accessed 20 Aug. 2018.

Genovese, Eugene D. The Political Economy of Slavery: Studies in the Economy and Society of the Slave South. 1961. New York: Vintage, 1967. Print.

Giovanni, Nikki. Blues: For All the Changes. New York: William Morrow, 1999. Print.

Gordon, Sarah H. Passage to Union: How the Railroads Transformed American Life, 1829-1929. Chicago: Ivan R. Dee, 1996. Print.

Harris, Trudier. The Scary Mason-Dixon Line: African American Writers and the South. Baton Rouge: Louisiana State UP, 2009. Print.

Jacobs, Harriet. Incidents in the Life of a Slave Girl. Written by Herself. 1881. Electronic 
edition. Chapel Hill: U of North Carolina P, 2003.

https://docsouth.unc.edu/fpn/jacobs/jacobs.html. Accessed 20 Aug. 2018.

Jones, James H. Bad Blood: The Tuskegee Syphilis Experiment. New York: Free Press, 1993. Print.

Jones, Radhica. "6 Questions: Colson Whitehead." Time 22 Aug. 2016: 48.

Kendi, Ibram X. Stamped from the Beginning: The Definitive History of Racist Ideas in America. New York: Basic, 2016. Print.

Larson, Kate Clifford. Bound for the Promised Land: Harriet Tubman, Portrait of an American Hero. New York: One World, 2003. Print.

Lucas, Julian. "New Black Worlds to Know." New York Review of Books 63.14 (29 Sept. 2016): 56-57.

Morrison, Toni. Home. London: Chatto \& Windus, 2012. Print.

Muhammad, Khalil Gibran. The Condemnation of Blackness: Race, Crime, and the Making of Modern Urban America. Cambridge: Harvard UP, 2010. Print.

Patterson, Orlando. Slavery and Social Death: A Comparative Study. Cambridge: Harvard UP, 1982. Print.

Patrick, Diane. "Tunnel Visions." Publisher's Weekly 25 Jul. 2016: 27-28.

Roberts, Dorothy. "Black Women and the Pill." Family Planning Perspectives 32.2 (March/April 2000): 92-93.

https://www.guttmacher.org/journals/psrh/2000/03/forum-black-women-andpill. Accessed Jul. 23, 2018.

Rushdy, Ashraf H. "Slavery and Historical Memory in Late-Twentieth-Century Fiction." The Cambridge Companion to Slavery in American Literature. Ed. Ezra Tawil. Cambridge: Cambridge UP, 2016. 236-49. Print.

Schuessler, Jennifer. "Colson Whitehead on Slavery, Success and Writing the Novel That Really Scared Him.” New York Times 2 Aug. 2016.

https://www.nytimes.com/2016/08/04/books/colson-whitehead-on-slaverysuccess-and-writing-the-novel-that-really-scared-him.html. Accessed 20 Aug. 2018.

Sinha, Manisha. The Slave's Cause: A History of Abolition. New Haven: Yale UP, 2016. Print.

Walker, Alice. "In Search of Our Mothers' Gardens." 1974. In Search of Our Mothers' Gardens: Womanist Prose, by Alice Walker. San Diego: Harcourt, 1984. 23143. Print.

Whitehead, Colson. The Underground Railroad. London: Fleet, 2016. Print.

Zabel, Darcy A. The (Underground) Railroad in African American Literature. New York: Peter Lang, 2004. Print. 